\title{
Interaction Effect of Seasonal Variations on the Presence of Heavy Metals in the Environment and Ready-to-Eat Food in Parts of Port Harcourt Metropolis
}

\author{
Oyet Gogomary Israel", Achinewhu Simeon Chituru, Kiin-Kabari David Barine, \\ Akusu Ohwesiri Monday
}

Department of Food Science and Technology, Faculty of Agriculture, Rivers State University, Port Harcourt, Nigeria

Email address:

gogomaryo@yahoo.com (O. G. Israel)

${ }^{*}$ Corresponding author

To cite this article:

Oyet Gogomary Israel, Achinewhu Simeon Chituru, Kiin-Kabari David Barine, Akusu Ohwesiri Monday. Interaction Effect of Seasonal Variations on the Presence of Heavy Metals in the Environment and Ready-to-Eat Food in Parts of Port Harcourt Metropolis. International Journal of Food Science and Biotechnology. Vol. 5, No. 2, 2020, pp. 21-30. doi: 10.11648/j.ijfsb.20200502.13

Received: April 21, 2020; Accepted: May 7, 2020; Published: June 4, 2020

\begin{abstract}
The presence of heavy metals in the environment and ready-to-eat street food were investigated to determine the interaction effect of seasonal variations on food safety in parts of Port Harcourt city. The study was carried out using complete randomization design in factorial experiment. The experiment was conducted in dry and wet seasons along the 3 locations (Makoba- 1, Elekahia- 2 and Rivers State University-3). The Six Food products studied were roasted plantain, fish, yam, suya, meat pie and doughnuts. Lead, Cadmium, Nickel, Mercury and Arsenic in Foods and Environment were examined. Heavy metal distribution in ambient air from stations 1-3 showed Cadmium (Cd) ranged from $<0.01 \mathrm{mg} / 100 \mathrm{~g}-0.2154 \mathrm{mg} / 100 \mathrm{~g}$, with significantly high value of $0.2154 \mathrm{mg} / 100 \mathrm{~g}$ observed at Elekahia during the raining season. Arsenic was detected from Makoba at raining season and stations 1 and 2 during the dry season, with values of $0.0057 \mathrm{mg} / 100 \mathrm{~g}, 0.0104 \mathrm{mg} / 100 \mathrm{~g}$ and $0.0099 \mathrm{mg} / 100 \mathrm{~g}$, respectively. Nickel values were negligible $(<0.001)$. Lead values $0.0492 \mathrm{mg} / 100 \mathrm{~g}$ and $0.0650 \mathrm{mg} / 100 \mathrm{~g}$ were seen only at Makobar during the raining and dry seasons. The presence of Lead during the dry season was significantly different $(\mathrm{P}<0.05)$ higher value of $0.0650 \mathrm{mg} / 100 \mathrm{~g}$ at Makoba than the raining season. Cadmium $(\mathrm{Cd})$ value of $0.0023 \mathrm{mg} / 100 \mathrm{~g}$ each were detected in roasted Yam (RY1) and Doughnut (DN1) from Makobar, while Lead, Arsenic, Nickel and Mercury were not detected in any of the Ready-to eat food samples during the raining season. Cd values of $0.003 \mathrm{mg} / 100 \mathrm{~g}, 0.003 \mathrm{mg} / 100 \mathrm{~g}$ and $0.004 \mathrm{mg} / 100 \mathrm{~g}$ were detected in roasted plantain (RP1, RP3), and roasted fish (RF2), respectively. Arsenic was noticed in suya (SY1-3) values of $0.025,0.010$ and $0.005 \mathrm{mg} / 100 \mathrm{~g}$, respectively. While, Ni was only detected in meat pie (MP1 and MP2) $(0.06 \mathrm{mg} / 100 \mathrm{~g}$ each). Lead and Mercury were not detected at dry season. The interaction effects of season and location on heavy metal deposit in ready -to-eat-street foods showed that while Cd was detected at levels of $0.0023 \mathrm{mg} / 100 \mathrm{~g}$ in roasted yam and doughnut from Makobar during the raining season, $\mathrm{Cd}$ was not present in same foods during the dry season. Arsenic was high during the dry season at Makobar, but not detected during the raining season. Nickel was present at level of $0.006 \mathrm{mg} / 100 \mathrm{~g}$ in meat pie during the dry season but not detected during the raining season. Further work on the comprehensive outdoor air quality and street food quality in Port Harcourt metropolis to serve as a protection to public health and consumer interest is hereby suggested.
\end{abstract}

Keywords: Interaction Effect, Dry and Wet Season, Heavy Metals, Contaminations, Environment, Ready-to-Eat Street Foods

\section{Introduction}

Information on the hazards and dangers posed by Ready-to-eat street foods or in-depth studies on the adverse effects of the consumption of these foods have not been made. These vended foods are sold around unclean environment, characterized with environmental pollutants and contaminants of various sources. Heavy metal pollution has been considered as one of the major ecological threat to man and other organisms especially through food chain when found above the threshold concentrations [1].

Ready-to-eat Street Vended food are hawked around oil installations, especially truck terminals for lifting refined 
petroleum products across the country. The drivers of these trucks or tankers, mostly of low education with poor knowledge of food safety are prone to patronizing these Ready-to-eat Street vended foods. Also, around the University car park, where various grades of vehicles are used in transportation of students, with various emissions and particulate matters. Most students' users may be unaware of the danger posed by the chemical and microbiological load of the street Vended food, as occasionally people have complained of stomach pain and diarrhea in some instances. However, the chemical hazards posed by heavy metals appears hidden to the users.

The exposing of foods to heavy chemicals has created serious concerns in the public health sector. Heavy metals accumulation and bio-magnification poses severe risks as they are toxic and could hamper the food chain [2]. It is pertinent to investigate the concentration levels of the heavy metals since the process for their deposition is bio-accumulation in the environment and Vended ready-to-eat street foods in order to predict possible extents of consumer vulnerability to these toxic materials due to inhalation and assimilation. Heavy metals displace vital elements and obstruct their biological functions. These metals get into the body through food consumption, skin exposure, beverages, and air inhalation. Exposure of heavy metals by any means of food consumption will have confirmative negative effects to human health [3], Cadmium pathways into the atmosphere are usually due to industrial processes [4]. Those that has been initiated by the activities of industries has been estimated to be greater than natural sources within a great magnitude [5]. Processes that involve the smelting of Cadmium, Copper, Zinc and Lead are said to be the major sources of Cadmium emission; other urban and industrial emissions; phosphate fertilizer manufacture; dust from roads; municipal and incinerators for sewage handling $[6,7]$.

Ekpo et al. [8] reported that metals such as Lead $(\mathrm{Pb})$, Arsenic (As), Cadmium (Cd), and Mercury ( $\mathrm{Hg}$ ) have been known to be of no use in the body, but can enter through inhalation, but uptake from soil, water and waste. Some metals are regarded as essential in humans (e.g. Iron, Zinc, Copper, Manganese, Arsenic, Chromium, etc.) whose primary role is to serve as a catalyst; and only trace amounts are required for cellular function. Mohammed, et al. [9] cited the work of Sobukola, et al. [10], and reported that "various human activities such as emissions from vehicle exhausts, used of fossil fuels and spent oil, traffic density, mining, industrial waste, fertilizer application, paint, chemical used in treated woods, plastic floating on the world oceans, aging water supply infrastructure, war zones and corrosion of metals are known to be the major sources of these metals."

For example, Mercury causes harm to nerves while lung diseases can be caused by Arsenic. Impacts of $\mathrm{Pb}$ on man incorporate general metabolic toxic substance which aggregates in body tissues, red platelets liver and kidneys. Noxious levels of different doses of $\mathrm{Pb}$ introduction join extraordinary encephalopathy which is depicted by non-attendance of co-arrangement, disorder, extending of the cerebrum and seizure and it may prompt epilepsy, stupor state or in any event, passing [11]. On man, chromium has exacerbation impacts on skin and nasal tissues, it causes bronchitis, pneumonitis, gastro - intestinal, hepatic and renal impedances similarly as beginning life form harmful quality and distinctive damaging ramifications for augmentation [12]. Mercury is up to speed in gastro intestinal tract, expends skin, lungs. It impacts uterine mucosa. It also impacts liver, personality, kidney and eyes [13].

\section{Materials and Methods}

\subsection{Study Area}

Port Harcourt is the Headquarter and major metropolis in River State, located between the latitudes of $4^{\circ} 46^{\prime} 38.71^{\prime \prime} \mathrm{N}$ and longitudes $7^{\circ} 00^{\prime} 48.24^{\prime \prime} \mathrm{E}$ in the core of South-South. The Study was conducted in some selected parts of Port Harcourt metropolis, Rivers States along the following sampling locations: Makoba: Terminal and Depots (Housing Oil and Gas, Truck Park/slump environment), Rivers State University gate (Urban- Academic Environment) Elekahia (urbandefining Industrial and Residential Area). [42]

\subsection{Methods}

\subsubsection{Experimental Design}

Six food samples each were purchased from the 3 (three) locations in Port Harcourt City for two different days respectively and were wrapped with an aluminum foil paper, transported in an iced cooler to Rofnel Energy Services, Food Chemistry and Environmental Laboratory located at Plot 2 Adison Close, Rumuagholu, Port Harcourt, Rivers State, Nigeria same day for analysis. One Air filter paper unexposed as control.

The whole study was done using complete randomized design in a factorial experiment. Three factorials were used (Factors A, B and C); factor A represented Season, B Location and $\mathrm{C}$ Ready-to-eat Street Vended food samples given as $2 \times 3 \times 6$ factorials. The vended foods are as shown in Table 1 using the previous method of Oyet et al. [42].

\subsubsection{Sample Collection}

A total of 18 (Eighteen) food samples consisting of roasted fish, roasted plantain, roasted yam, Meat Pie, Suya and Doughnut were purchased from ready -to-eat food vendors and hawkers along Makobar-Industrial settlement, Elekahia-Urban dwellers, Rivers State University Gate, and 3 (three) Filter Papers all in Port Harcourt city, Rivers State, Nigeria.

Table 1. Experimental Design: Season, Locations and Food Samples.

\begin{tabular}{llll}
\hline SEASON & STATION 1 & STATION 2 & STATION 3 \\
\hline Raining & RP1 & RP2 & RP3 \\
\hline
\end{tabular}




\begin{tabular}{llll}
\hline SEASON & STATION 1 & STATION 2 & STATION 3 \\
\hline$\&$ & RF1 & RF2 & RF3 \\
Dry & RY1 & RY2 & RY3 \\
& SY1 & SY2 & SY3 \\
& MP1 & MP2 3 \\
& DN1 & DN2 & DN3 \\
& P1 & P2 & P3 \\
\hline
\end{tabular}

Legends:

RP1=Roasted plantain from Makobar, Port Harcourt.

RP2 $=$ Roasted plantain from Elekahia, Port Harcourt.

RP3=Roasted plantain from Rivers State University, Port Harcourt.

RF1=Roasted fish from Makobar, Port Harcourt.

RF2=Roasted fish from Elekahia, Port Harcourt.

RF3=Roasted fish from Rivers State University, Port Harcourt.

RY1=Roasted yam from Makobar, Port Harcourt.

RY2=Roasted yam from Elekahia, Port Harcourt.

RY3=Roasted yam from Rivers State University, Port Harcourt.

SY1=Roasted suya from Makobar, Port Harcourt.

SY2=Roasted suya from Elekahia, Port Harcourt.

SY3=Roasted suya from Rivers State University, Port Harcourt.

MP1=Baked meat pie from Makobar, Port Harcourt.

MP2=Baked meat pie from Elekahia, Port Harcourt.

MP3=Baked meat pie from Rivers State University, Port Harcourt.

DN1 $=$ Fried dough nut from Makobar, Port Harcourt.

DN2=Fried dough nut from Elekahia, Port Harcourt.

DN3=Fried dough nut from Rivers State University, Port Harcourt.

P1=Air Filter paper unexposed as control at Makobar, Port Harcourt.

P2=Air Filter paper unexposed control at Elekahia, Port Harcourt.

P3=Air Filter paper unexposed as control at Rivers State University, Port Harcourt.

Eighteen (18) samples were collected along the three (3) different locations for two (2) day during each season. They were wrapped in an aluminum foil, placed in a cooler and taken to the laboratory from which sub-samples were obtained for the determination of Heavy metals in Foods. The choice of the samples were carefully made to reflect the most consumed Ready - to - eat street vended foods in Port-Harcourt. The samples were stored at $4^{\circ} \mathrm{C}$ prior to analysis.

\subsection{Methodology for Heavy Metals Sampling in the Environment}

Hi-volume sampler Model H2000 was used for trapping particles. Here, a known volume of ambient air is drawn through a glass fibre filter $(20 \times 25 \mathrm{~cm})$ by means of a heavy duty turbine blower with flow rate ranging from 1.1 $1.7 \mathrm{~m}^{3} / \mathrm{min}$ [14], Metals were removed from the air stream by adsorption and filtration on the glass fiber filter. The filter was being digested with appropriate reagents followed by direct aspiration into the AAS. Metal results were displayed on attached computer system.

\subsection{Determination of Lead, Cadmium, Nickel Mercury and Arsenic in Foods by Atomic Absorption Spectrophotometer}

The method of APHA $3114 \mathrm{~B}$ was used for $\mathrm{Ni}, \mathrm{Pb}$, and $\mathrm{As}$, while APHA $3111 \mathrm{C}$ was used for Cd. Buck Scientific AAS-210 VGP was the model used for $\mathrm{Ni}, \mathrm{Pb}, \mathrm{Cd}$, and $\mathrm{As}$ and located at Rofnel Energy Services Limited, located at Plot 2 Adison Close, Rumuagholu, Port Harcourt [15].

\subsection{Data Analysis}

The mean values of the data obtained from this study were subjected to statistical calculations which were performed using Analysis of Variance (ANOVA) and IBM SPSS (Statistical Package for Social Sciences) version 21.

\section{Results and Discussion}

Table 2. Heavy Metal Content of Ambient Air during the Raining and Dry Season.

\begin{tabular}{|c|c|c|c|c|c|c|}
\hline \multirow{2}{*}{ Season } & \multirow{2}{*}{ Station } & Cd & As & $\mathbf{N i}$ & \multirow{2}{*}{$\mathrm{Pb}(\mathrm{mg} / 100 \mathrm{~g})$} & \multirow{2}{*}{$\begin{array}{l}\mathrm{Hg} \\
(\mathrm{mg} / 100 \mathrm{~g})\end{array}$} \\
\hline & & $(\mathrm{mg} / 100 \mathrm{~g})$ & $(\mathrm{mg} / 100 \mathrm{~g})$ & $(\mathrm{mg} / 100 \mathrm{~g})$ & & \\
\hline \multirow[t]{3}{*}{ Raining } & 1 & $0.0571^{b} \pm 0.0001$ & $0.0057^{\mathrm{a}} \pm 0.0001$ & $<0.001$ & $0.0492^{\mathrm{b}} \pm 0.0001$ & $<0.001$ \\
\hline & 2 & $0.0333^{\mathrm{c}} \pm 0.0001$ & $<0.001$ & $<0.001$ & $<0.001$ & $<0.001$ \\
\hline & 3 & $0.2154^{\mathrm{a}} \pm 0.0001$ & $<0.001$ & $<0.001$ & $<0.001$ & $<0.001$ \\
\hline Unexposed Paper & & $<0.001$ & $<0.001$ & $<0.001$ & $<0.001$ & $<0.001$ \\
\hline \multirow[t]{3}{*}{ Dry } & 1 & $0.0123^{\mathrm{d}} \pm 0.0013$ & $0.0104^{\mathrm{a}} \pm 0.0090$ & $<0.001$ & $0.0650^{\mathrm{a}} \pm 0.0010$ & $<0.001$ \\
\hline & 2 & $0.0031^{\mathrm{e}} \pm 0.0013$ & $0.0099^{\mathrm{a}} \pm 0.0085$ & $<0.001$ & $<0.001$ & $<0.001$ \\
\hline & 3 & $<0.001$ & $<0.001$ & $<0.001$ & $<0.001$ & $<0.001$ \\
\hline
\end{tabular}




\begin{tabular}{|c|c|c|c|c|c|c|}
\hline & & $\mathrm{Cd}$ & As & $\mathrm{Ni}$ & & $\mathrm{Hg}$ \\
\hline Season & Station & $(\mathrm{mg} / 100 \mathrm{~g})$ & $(\mathrm{mg} / 100 \mathrm{~g})$ & $(\mathrm{mg} / 100 \mathrm{~g})$ & $\mathrm{Pb}(\mathrm{mg} / 100 \mathrm{~g})$ & $(\mathrm{mg} / 100 \mathrm{~g})$ \\
\hline Unexposed Paper & & $<0.001$ & $<0.001$ & $<0.001$ & $<0.001$ & $<0.001$ \\
\hline
\end{tabular}

Values are means \pm standard deviation of triplicate samples.

Mean values bearing different superscripts in the same column differ significantly $(\mathrm{p}<0.05)$.

Key: $\mathrm{Cd}=$ Cadmium

$\mathrm{As}=$ Arsenic.

$\mathrm{Ni}=$ Nickel.

$\mathrm{Pb}=$ Lead.

$\mathrm{Hg}=$ Mercury.

Station 1=Makoba.

Station 2=Elekahia.

Station 3=Rivers|State University.

Table 3. Heavy Metal Content in Ready-to-eat Street Vended Foods during the Raining Season.

\begin{tabular}{llllll}
\hline Samples & $\mathbf{C d}(\mathbf{m g} / \mathbf{1 0 0 g})$ & $\mathbf{P d}(\mathbf{m g} / \mathbf{1 0 0 g})$ & $\mathbf{A s}(\mathbf{m g} / \mathbf{1 0 0 g})$ & $\mathbf{N i}(\mathbf{m g} / \mathbf{1 0 0 g})$ & $\mathbf{H g}(\mathbf{m g} / \mathbf{1 0 0 g})$ \\
\hline RP1 & 0 & 0 & 0 & 0 & 0 \\
RP2 & 0 & 0 & 0 & 0 & 0 \\
RP3 & 0 & 0 & 0 & 0 & 0 \\
RF1 & 0 & 0 & 0 & 0 & 0 \\
RF2 & 0 & 0 & 0 & 0 & 0 \\
RF3 & 0 & 0 & 0 & 0 & 0 \\
RY1 & $0.0023^{\mathrm{a}} \pm 0.00$ & 0 & 0 & 0 & 0 \\
RY2 & 0 & 0 & 0 & 0 & 0 \\
RY3 & 0 & 0 & 0 & 0 & 0 \\
SY1 & 0 & 0 & 0 & 0 & 0 \\
SY2 & 0 & 0 & 0 & 0 & 0 \\
SY3 & 0 & 0 & 0 & 0 & 0 \\
MP1 & 0 & 0 & 0 & 0 & 0 \\
MP2 & 0 & 0 & 0 & 0 & 0 \\
MP3 & 0 & 0 & 0 & 0 & 0 \\
DN1 & $0.0023^{\mathrm{a}} \pm 0.00$ & 0 & 0 & 0 & 0 \\
DN2 & 0 & 0 & 0 & 0 & 0 \\
DN3 & 0 & 0 & 0 & 0 & 0 \\
PAPER1 & 0 & 0 & 0 & 0 & 0 \\
PAPER2 & 0 & 0 & 0 & 0 \\
PAPER3 & 0 & 0 & 0 & 0 \\
\hline
\end{tabular}

Values are means \pm standard deviation of triplicate samples.

Mean values bearing different superscripts in the same column differ significantly $(\mathrm{p}<0.05)$.

Key: $\mathrm{Cd}=$ Cadmium, $\mathrm{As}=$ Arsenic, $\mathrm{Ni}=$ Nickel, $\mathrm{Pb}=\mathrm{Lead}, \mathrm{Hg}=$ Mercury.

$\mathrm{RP} 1=$ roasted plantain from Makobar, Lagos.

RP2=roasted plantain from Elekahia, Port Harcourt.

RP3=roasted plantain from Rivers State University, Port Harcourt.

RF1=roasted fish from Makobar, Port Harcourt.

RF2=roasted fish from Elekahia, Port Harcourt.

RF3=roasted fish from Rivers State University, Port Harcourt.

RY1=roasted yam from Makobar, Port Harcourt.

RY2=roasted yam from Elekahia, Port Harcourt.

RY3=roasted yam from Rivers State University, Port Harcourt.

SY1=suya from Makobar, Port Harcourt.

SY2=suya from Elekahia, Port Harcourt.

$\mathrm{SY} 3=$ suya from Rivers State University, Port Harcourt.

MP1=meat pie from Makobar, Port Harcourt.

MP2=meat pie from Elekahia, Port Harcourt.

MP3=meat pie from Rivers State University, Port Harcourt.

DN1=dough nut from Makobar, Port Harcourt.

DN2=dough nut from Elekahia, Port Harcourt.

DN3=dough nut from Rivers State University, Port Harcourt.

Table 4. Heavy Metal Content of Ready-to-eat Street Vended Foods during the Dry Season.

\begin{tabular}{llllll}
\hline Samples & Cd (mg/100g) & Pd (mg/100g) & As (mg/100g) & Ni (mg/100g) & Hg (mg/100g) \\
\hline RP1 & $0.003^{\mathrm{b}} \pm 0.001$ & 0 & 0 & 0 & 0 \\
RP2 & 0 & 0 & 0 & 0 & 0 \\
RP3 & $0.003^{\mathrm{b}} \pm 0.001$ & 0 & 0 & 0 & 0 \\
RF1 & 0 & 0 & 0 & 0 & 0 \\
\hline
\end{tabular}


Oyet Gogomary Israel et al: : Interaction Effect of Seasonal Variations on the Presence of Heavy Metals in the Environment and Ready-to-Eat Food in Parts of Port Harcourt Metropolis

\begin{tabular}{|c|c|c|c|c|c|}
\hline Samples & $\mathrm{Cd}(\mathrm{mg} / \mathbf{1 0 0 g})$ & Pd (mg/100g) & As (mg/100g) & $\mathrm{Ni}(\mathrm{mg} / \mathbf{1 0 0 g})$ & $\mathrm{Hg}(\mathrm{mg} / 100 \mathrm{~g})$ \\
\hline RF2 & $0.004^{\mathrm{b}} \pm 0.001$ & 0 & 0 & 0 & 0 \\
\hline RF3 & 0 & 0 & 0 & 0 & 0 \\
\hline RY1 & 0 & 0 & 0 & 0 & 0 \\
\hline RY2 & 0 & 0 & 0 & 0 & 0 \\
\hline RY3 & 0 & 0 & 0 & 0 & 0 \\
\hline SY1 & 0 & 0 & $0.025^{\mathrm{a}} \pm 0.009$ & 0 & 0 \\
\hline SY2 & 0 & 0 & $0.010^{\mathrm{b}} \pm 0.009$ & 0 & 0 \\
\hline MP1 & 0 & 0 & 0 & 0 & 0 \\
\hline MP2 & 0 & 0 & 0 & $0.006^{\mathrm{a}} \pm 0.005$ & 0 \\
\hline MP3 & 0 & 0 & 0 & $0.006^{\mathrm{a}} \pm 0.005$ & 0 \\
\hline DN1 & 0 & 0 & 0 & 0 & 0 \\
\hline DN2 & 0 & 0 & 0 & 0 & 0 \\
\hline DN3 & 0 & 0 & 0 & 0 & 0 \\
\hline PAPER1 & $0.012^{\mathrm{a}} \pm 0.001$ & 0 & $0.010^{\mathrm{b}} \pm 0.009$ & 0 & 0 \\
\hline
\end{tabular}

Values are means \pm standard deviation of triplicate samples.

Mean values bearing different superscripts in the same column differ significantly $(\mathrm{p}<0.05)$.

Key: $\mathrm{Cd}=$ Cadmium, $\mathrm{As}=$ Arsenic, $\mathrm{Ni}=$ Nickel, $\mathrm{Pb}=$ Lead, $\mathrm{Hg}=$ Mercury.

RP1=roasted plantain from Makobar, Port Harcourt.

RP2=roasted plantain from Elekahia, Port Harcourt.

RP3=roasted plantain from Rivers State University, Port Harcourt.

RF1=roasted fish from Makobar, Port Harcourt.

RF2=roasted fish from Elekahia, Port Harcourt.

RF3=roasted fish from Rivers State University, Port Harcourt.

RY1=roasted yam from Makobar, Port Harcourt.

RY2=roasted yam from Elekahia, Port Harcourt.

RY3=roasted yam from Rivers State University, Port Harcourt.

SY1=suya from Makobar, Port Harcourt.

SY2=suya from Elekahia, Port Harcourt.

SY3=suya from Rivers State University, Port Harcourt.

MP1=meat pie from Makobar, Port Harcourt.

$\mathrm{MP} 2=$ meat pie from Elekahia, Port Harcourt.

MP3=meat pie from Rivers State University, Port Harcourt.

DN1=dough nut from Makobar, Port Harcourt.

DN2=dough nut from Elekahia, Port Harcourt.

DN3=dough nut from Rivers State University, Port Harcourt.

Table 5. Correlation Matrix between seasonal Variation and Heavy Metals in Street Vended Foods.

\begin{tabular}{|c|c|c|c|c|}
\hline & Cd (Raining) & Pb (Raining) & As (Raining) & Ni (Raining) \\
\hline $\mathrm{Pb}$ (Raining) & * & & & \\
\hline As (Raining) & * & * & & \\
\hline Ni (Raining) & * & * & * & \\
\hline Cd (Dry) & $\begin{array}{l}-0.161 \\
0.486\end{array}$ & * & * & * \\
\hline $\mathrm{Pb}$ (Dry) & * & * & * & * \\
\hline As (Dry) & $\begin{array}{l}-0.152 \\
0.510\end{array}$ & * & * & * \\
\hline Ni (Dry) & $\begin{array}{l}-0.105 \\
0.650\end{array}$ & * & $\begin{array}{l}* \\
*\end{array}$ & $\begin{array}{l}* \\
*\end{array}$ \\
\hline
\end{tabular}

\begin{tabular}{llll}
\hline & Cd (Dry) & Pb (Dry) & As (Dry) \\
\hline $\mathrm{Pb}$ (Dry) & $*$ & & \\
& $*$ & $*$ & $*$ \\
$\mathrm{As}$ (Dry) & 0.189 & $*$ & -0.152 \\
$\mathrm{Ni}$ (Dry) & 0.413 & $*$ & 0.510 \\
& -0.161 & 0.486 & \\
\hline
\end{tabular}

Cell Contents: Pearson correlation, P-Value.

*Identical (not detected). 
This research was aimed to investigate the Interaction effects of seasonal variations on the heavy metals distribution in the Environment and Ready -to-eat street vended food in parts of Port Harcourt City.

\subsection{Heavy Metal Distribution in Ambient Air During Wet and Dry Season}

Table 2 shows the analysis of Heavy metal distribution in ambient air from stations 1 (Makoba), 2 (Elekahia) and 3 (Rivers State University). The results showed that $\mathrm{As}$ and $\mathrm{Pb}$ were present in trace concentrations at stations 1 and 2 during both seasons, however $\mathrm{Ni}$ and $\mathrm{Hg}$ were not detected at any station. Cadmium was the only metals detected across the three stations with values ranging from 0.0333 to 0.2154 $\mathrm{mg} / 100 \mathrm{~g}$ during raining and dry season. These values were above the regulatory tolerance limit of $0.0003 \mathrm{mg} / 100 \mathrm{~g}$ for 24 hours and $0.001 \mathrm{mg} / 100 \mathrm{~g}$ for 30 minutes exposure [16].

Cadmium (Cd) with significantly high value of $0.2154 \mathrm{mg} / 100 \mathrm{~g}$ was observed in ambient air at station 3 (RSU) during the raining season. However, the value of Cadmium (Cd) $0.0123 \mathrm{mg} / 100 \mathrm{~g}$, detected during the dry season at station 1 (Makoba) was lower than the values detected in the ambient air station 3 (RSU) during the raining season. Cadmium is relatively volatile elements of no essential values to plants, animals and humans. According to Smirjakova et al. [17], Lead and Cadmium are toxic and in very low concentrations can cause metabolic anomalies. The result of this study implicated the presence of high Cadmium within the operating environment of Makoba, Elekahia and the Rivers State University gate during the dry and raining season respectively.

The work of Morrow [7], supported the presence of Cadmium within the studied locations when the study reported that Cadmium can be released into the atmosphere from both natural and anthropogenic sources such as burning of fossil fuels, vehicle exhaust, soots and particulate matters. However, industrial activities such as urban and industrial emissions; phosphate fertilizer manufacture; road dust; municipal and sewage sludge incinerators are the main sources of cadmium release to air [4, 6]. Emissions from anthropogenic sources have been found to exceed those of natural origin by an order of magnitude [5] Arsenic was recorded only in air from station 1 (Makobar at raining season) and stations 1 and 2 (Elekahia) during the dry season respectively. Arsenic had a value of $0.0057 \mathrm{mg} / 100 \mathrm{~g}$ which was observed in station 1 (Makoba) during the wet season, however, $0.0104 \mathrm{mg} / 100 \mathrm{~g}$ and 0.0099 $\mathrm{mg} / 100 \mathrm{~g}$ at station 1 and 2 were recorded in the dry season. Generally, levels of Arsenic observed were below the National tolerance limit of $20-100 \mathrm{mg} / \mathrm{m}^{3}$ for specific pollutants [16]. Ekpo et al. [8] reported that metals such as $\mathrm{Pb}, \mathrm{As}, \mathrm{Cd}$, and $\mathrm{Hg}$ have been known to be of no use in the body, but can enter through inhalation. Thus, there is high possibility for the inhalation of Arsenic at the locations. They were recorded as pollutants. Nickel values were negligible $(<0.001)$.

From Table 2 Lead $(\mathrm{Pb})$ values $0.0492 \mathrm{mg} / 100 \mathrm{~g}$ and $0.0650 \mathrm{mg} / 100 \mathrm{~g}$ were detected only in air at Makobar during the raining and dry seasons as against the National tolerance limit of $0.0005 \mathrm{mg} / 100 \mathrm{~g}$ for 24 hours and $0.0002 \mathrm{mg} / 100 \mathrm{~g}$ for 30 minutes [16] The presence of Lead during the dry season was significantly different $(\mathrm{P}<0.05)$ higher value of $0.0650 \mathrm{mg} / 100 \mathrm{~g}$ at station 1 than the (raining season).

Humans may be exposed to lead from air pollution directly, through inhalation, or through the incidental ingestion of lead that has settled out from the air onto soil or dust.

This is evidence in our daily exposures in Port Harcourt as the nostrils when cleaned with white handkerchief showed black collections due to long exposure to the environment that was laden with smoke and soots from exhaust of heavy vehicles and other anthropogenic sources. Lead can adversely affect the nervous system, kidney function, immune system, reproductive and developmental systems, and the cardiovascular system. Lead exposure also affects the oxygen-carrying capacity of the blood [18] and capable of being vertical toxicity from mother to child [19]. Toxic effects of different levels of lead exposure include acute encephalopathy which is characterized by lack of co-ordination, confusion, swelling of the brain and seizure and it may induce epilepsy, coma or even death [11].

The presence of lead in Makoba is a major source of public health concerns for the numbers of people working and leaving in Makoba area of Port Harcourt and more worrisome is for the children and the elderly who are residents of Makoba. This findings agrees with the work of Ajayi and Kamson, [20], Ogunsola et al., [21]; Onianwa and Egunyomi, [22], "That Industrialization has also resulted in concentration of many chemicals in the atmosphere from where it enters into body fluids and different environmental media of soil, water, air, food, amongst others". The work of Audu et al. [23], reported that pollutants from vehicles include $\mathrm{SO}_{\mathrm{X}}, \mathrm{NO}_{\mathrm{X}}, \mathrm{COX}$, and $\mathrm{Pb}$.

Factorial interaction effects of season and location on heavy metal distribution in ambient air were significant $(\mathrm{P}<0.05)$ as shown in table 2. Cadmium (Cd) content was high $(0.2154 \mathrm{mg} / 100 \mathrm{~g})$ at station 3 during the raining season and negligible $(<0.001)$ during the dry season. Arsenic (As) was significantly $(\mathrm{P}<0.05)$ higher during the dry season at stations 1 and 2, but negligible at station 3. Seasonal effect was observed on the distribution pattern of each of the heavy metals.

It was observed that the impact of seasonal variations on heavy metal distribution was significantly higher in dry season than in the raining season except for Cadmium, which recorded higher Cadmium $(\mathrm{Cd})$ content of $(0.2154 \mathrm{mg} / 100 \mathrm{~g})$ at station 3 during the raining season and negligible $(<0.001)$ during the dry season. The findings in this study collaborated with the work by Ede and Edokpa [24], which concluded that the phenomenon of black soot over Port Harcourt was most evident in the peak of the last dry season (December 2016-February 2017), [25], and Shell Petroleum Development Company [26],

\subsection{Heavy Metal Deposits' in Ready-to-Eat Street Vended Foods During the Raining Season}

Table 3 showed that Heavy metals were detected in some 
Ready-to-eat street vended foods such as Roasted Yam (RY1) and Doughnuts (DN1) during the raining season. The study showed the presence of Cadmium $(\mathrm{Cd})$ value of $0.0023 \mathrm{mg} / 100 \mathrm{~g}$. Similarly, Cd was not detected in the other street vended food samples such as RP1-3, RF1-3, RY2-3, SY1-3, MP1-3 and DN2-3.

Lead $(\mathrm{Pb})$, Arsenic (As), nickel (Ni) and mercury ( $\mathrm{Hg}$ ) were not detected in the following selected street vended food samples such as Meat pie, roasted Plantain, roasted Fish, Doughnut and Suya from all the stations (Makoba, Elekahia and RSU). The results in this study agreed with the work of Eke-Ejiofor and Maxwell, [27], that heavy metals such as lead and nickel content in the roasted plantain samples (Bole) were all $<0.001 \mathrm{mg} / \mathrm{kg}$ with no significant $(\mathrm{P}<0.005)$ different between each other. The levels of some selected heavy metals in the roasted plantain samples were found to be $<0.001$ which is below the permissive limit established by the WHO [34], from all the locations.

Cadmium $(\mathrm{Cd})$ value of $0.0023 \mathrm{mg} / 100 \mathrm{~g}$ each were detected in roasted yam (RY1) and doughnut (DN1) obtained from Makobar respectively. Cadmium is today regarded as the most serious contaminant of the modern age. It is absorbed by many plants and sea creatures and, because of its toxicity, presents a major problem for foodstuffs. Cadmium, like lead, is a cumulative poison, that is, the danger lies primarily in the regular consumption of foodstuffs with low contamination [28]. In a similar study by Jarup,[29], The Presence of high content of $\mathrm{Pb}$ and $\mathrm{Cd}$ in food is associated with cardiovascular, kidney, nervous as well as bone diseases. In a similar study by Oyelola et al. [30], cadmium of $0.06 \mathrm{mg} / \mathrm{g}$ was detected in Roasted Plantain in Iyana Ipaja and none in the other samples. Roasted plantain was seen to be high in various levels of contaminants such as heavy metals, which were as a result of high traffic. Vehicular emission is a major source of pollution of most ready-to-eat street vended foods [31, 32]. The results obtained from this study implicated the presence of high Cadmium within the operating environment of Makoba, Elekahia and the Rivers State University gate during the raining season.

Accordingly, the values of heavy metals present in the environment during the raining season was less compared to the values during the dry season and this may likely be one of the many reasons for the less contamination of the food samples during the raining season. Apart from cadmium, other heavy metals studied were not detected during the raining season in street vended food samples studied.

\subsubsection{Results of Heavy Metals in Ready-to-Eat Street Foods During the Dry Season}

The study highlighted the presence of heavy metals in vended street foods during the dry season as shown in Table 4. $\mathrm{Pb}$ and $\mathrm{Hg}$ were not detected in food during the dry season as well as the raining season. Therefore, one can infer that Ready-to eat vended street food does not pose serious threat with respect to the absence of lead and mercury. According to Eke-Ejiofor and Maxwell, [27], observed that since the level of heavy metals detected in the roasted plantain samples were generally below the maximum permissible limit set by World Health Organization, so the concentration of heavy metal may not be harmful to health. However, the presence of Cd, As and $\mathrm{Ni}$ is a major source of concerns to public health as they have the potential to cause serious harm at very low concentrations. $\mathrm{Cd}$ values of $0.003 \mathrm{mg} / 100 \mathrm{~g}, \quad 0.003 \mathrm{mg} / 100 \mathrm{~g}$ and $0.004 \mathrm{mg} / 100 \mathrm{~g}$ were observed in roasted Plantain and roasted Fish from Makobar (RP1), roasted Plantain from RSU (RP3) and roasted Fish from Elekahia (RF2), respectively. Arsenic (As) was noticed in suya only. Samples SY1, SY2 and SY3 gave Arsenic values of $0.025 \mathrm{mg} / 100 \mathrm{~g}, 0.010 \mathrm{mg} / 100 \mathrm{~g}$ and $0.005 \mathrm{mg} / 100 \mathrm{~g}$, respectively. $\mathrm{Ni}$ was detected in meat pie from stations 2 and $3(0.06 \mathrm{mg} / 100 \mathrm{~g}$ each). Williams, [19], reported that Cancers, heart and Lung Diseases (Pneumonitis), ulcers and hypersensitivity reaction especially "the nickel itch", Once a person develops allergy to nickel, it remains so for life. Therefore, vended street food samples implicated with the presence of Nickel is a serious health concerns.

High accumulation of nickel in the body may cause damage to liver, kidney, skin and brain. Nickel is also carcinogenic to human causing lungs and nasal cancer on acute exposure [33]. The concentration of nickel $(\mathrm{Ni})$ was only seen in meat pie from stations 2 and $3(0.06 \mathrm{mg} / 100 \mathrm{~g}$ each) which was above the $0.05 \mathrm{mg} / 100 \mathrm{~g}$ permissible limit set by WHO [34],, while in the other food samples across the three locations Ni were not detected and thus below the $0.05 \mathrm{mg} / 100 \mathrm{~g}$ permissible limit set by (FAO/WHO [35].

Cadmium exposure occurs through food, which represent a major route [36], in a similar study, the data obtained in respect of cadmium revealed that the level of the metal in the vended snacks was higher than the previously reported concentrations in food and drinks [37]. High level of cadmium in the body is very dangerous, causing bone disorder, cancer of the lungs, anemia and renal damage [38], Cadmium content of the vended food samples were found to be lower than the $0.2 \mathrm{mg} / \mathrm{kg}$ permissible limit set by WHO [34]. However, at low concentrations in food, $\mathrm{Cd}$ have been known to be of health concerns. SPDC [26], reported heavy presence of black soots and particulate matters during the dry season in Port Harcourt. According to the World Health Organization (WHO [39], soot deposited in air and food constitutes the largest among all of the environmental risks, recording death in low and middle-income countries, Cardiovascular Disease (CVDS), Chronic Obstructive Pulmonary Disease (COPD) and lung cancer, eye and skin disorder, Asthma, in industrial activities constitutes a principal source of the soot hazard [40]. Dry seasons with various metrological conditions is implicated as a precondition for many environmental pollutants as seen in the current study.

\subsubsection{Interaction Effect of Seasonal Variations and Location on Heavy Metals Deposits in Ready-to-Eat Street Vended Foods}

The study evaluated the effects of interaction of seasonal variations and location on heavy metal deposit in vended street foods. According to the results obtained from tables 3 and 4, Cadmium (Cd) was detected at levels of 
$0.0023 \mathrm{mg} / 100 \mathrm{~g}$ in roasted yam and doughnut from Makobar during the raining season, $\mathrm{Cd}$ was not detected in same foods during the dry season at the same stations. In addition, other heavy metals such as Nickel and Arsenic were detected during the dry season, the presence and sources of $\mathrm{Cd}$ detected during the raining season is not fully investigated. According to a study by EPA [4], Cadmium is released into the atmosphere from both natural and anthropogenic sources. However, industrial activities are the main sources of cadmium release to air [4]. Makoba is known for its many industrial activities including cement manufacturing, bitumen plant fired boilers and above all heavy duty trucks moving both refined petroleum products and dry good cargoes such as cements. According to Sobukola et al. [10], reported that additional sources of heavy metals such as Cadmium, Lead, Arsenic and Mercury in soil are due to rainfall in atmospheric contaminated area, traffic density, use of oil or fossil fuels for heating, use of plant protection agents and fertilizers. In recent time in Port Harcourt, we have witnessed increase in population growth, industrialization, oil exploration and exploitation, urbanization, uncontrolled dumping of both domestic and agricultural waste, and automobile exhaust have been implicated for the high rate of heavy metal contamination in vended street food.

The level of Arsenic, $(0.003 \mathrm{mg} / 100 \mathrm{~g})$ detected was high during the dry season at Makoba (station 1), but not detected during the raining season at the same station. In a similar results, Nickel (Ni) was present at level of $0.006 \mathrm{mg} / 100 \mathrm{~g}$ in meat pie during the dry season but not detected during the raining season.

Dry season was implicated by high volume of soots occasioned by increased activities of illegal bunkering and burning of intercepted products from illegal refineries along the Niger Delta creeks such as Makoba water front, Isaka and Bakana axis by security agencies (Rivers State Ministry of Environment, [25]. The industrial activities of heavy trucks generating dust along the road, and diesel engine exhaust incomplete combustion are possible contributors. This is mostly likely responsible for the increased presence of heavy metal deposit in food during dry season. Also, during raining season the inhabitants of Port Harcourt were known to collaborate the fact that they observed less soot's at home and within the environment as this may probably be accounted for the no deposit of heavy metals such as Arsenic and Nickel in the food samples. Accordingly, Williams, [19], reported that "a total of $408(81.9 \%)$ of respondents have observed soot more during dry season, than $78(15.7 \%)$ that observed soot more during wet season, $10(2.0 \%)$ observed soot during wet and dry seasons and $2(0.4 \%)$ did not answer the question". Thus, seasonal variations have effect on the presence of heavy metals on food samples during both season.

\subsubsection{Correlation between Seasonal Variation and Heavy Metal Deposit in Street Vended Foods}

A weak negative correlation was observed for cadmium, arsenic and nickel due to seasonal variation, with P-values ranging from $0.413-0.65$ in table 5 .
The implication is that we have variable (metals) increases in values, the second variable -the season was decreasing in value, and vice visa as we moved from raining season to dry season. You observed some correlation values during dry season, though with weak Pearson's ${ }^{\circledR}$ values. In most instances no value was detected, and in some instances, we have Pearson's values close to zero, showing a weak relationship between two variables, with the implication that changes in one variable (metals) are not correlated with changes in the second variable (season).

\section{Conclusion}

Heavy metals distribution in ambient air detected were $\mathrm{Cd}$, $\mathrm{As}, \mathrm{Ni}, \mathrm{Pb}$, and $\mathrm{Hg}$ during dry and raining seasons. Heavy metal results showed variability between the stations, metal like cadmium were present in toxic levels (0.0333 to $0.2154 \mathrm{mg} / 100 \mathrm{~g}$ ) around the studied stations, during raining and dry seasons. These values were above the FMEnv [16], regulatory tolerance limit of $0.0003 \mathrm{mg} / 100 \mathrm{~g}$ for $24 \mathrm{hrs}$ and $0.001 \mathrm{mg} / 100 \mathrm{~g}$ for 30 minutes exposure, while nickel and mercury were below detection limit across the study areas. However Lead value $(0.0492 \mathrm{mg} / 100 \mathrm{~g}$ to $0.0650 \mathrm{mg} / 100 \mathrm{~g})$ exceeded the National tolerance limit $(0.0005 \mathrm{mg} / 100 \mathrm{~g})$ for $24 \mathrm{hrs}$ and $0.0002 \mathrm{mg} / 100 \mathrm{~g}$ for 30 minutes exposure FMEnv,[16], at Makoba, during the raining and dry seasons and showed that the presence of lead during the dry season was significantly different $(\mathrm{P}<0.05)$ from the raining season. Arsenic $(0.0057 \mathrm{mg} / 100 \mathrm{~g})$ was observed at Makoba but the value was within the National tolerance limit $\left(20-100 \mathrm{mg} / \mathrm{m}^{3}\right)$.

According to Tapos et al., [41], in a study carried out on the concentrations of Heavy metals in foods, observed that the risk of Arsenic (As) as a carcinogen was higher than the USEPA standard $\left(10^{-4}\right)$, indicating increased risk of cancer for adults and children who patronized such foods in the study area.

The values of heavy metals present in the environment during the raining season was less compared to the values obtained during the dry season and this may likely be one of the many reasons for the less contamination of the food samples during the raining season. Apart from cadmium $(0.0023 \mathrm{mg} / 100 \mathrm{~g})$ found in (RY1 and DN1), other heavy metals studied were not detected during the raining season in street vended food samples. However, the presence of $\mathrm{Cd}$, As and $\mathrm{Ni} \quad(0.003 \mathrm{mg} / 100 \mathrm{~g}, \quad 0.025 \mathrm{mg} / 100 \mathrm{~g}, \quad 0.06 \mathrm{mg} / 100 \mathrm{~g})$ detected during the dry season in street vended food $(\mathrm{Cd}=\mathrm{RP} 1$, $\mathrm{RP} 3$, \& RF2, As $=\mathrm{SY} 1-3, \mathrm{Ni}=\mathrm{MP} 2-3$ ) is a major source of concerns to public health as they have the potential to cause serious harm at very low concentrations. Thus, seasonal variations have effect on the presence of heavy metals on food samples during both seasons. Also, the study showed a significant presence of heavy metals in the food samples which were extremely above the threshold set by WHO $(\mathrm{Cd}=0.2 \mathrm{mg} / \mathrm{kg} ., \quad \mathrm{As}=0.002 \mathrm{mg} / \mathrm{kg}, \quad \mathrm{Ni}=0.05 \mathrm{mg} / 100 \mathrm{~g})$ therefore, the presence of these substance in human diet is injurious, even though common heavy metals like lead was not detected. The interaction effect of seasonal variations and 
location on the presence of heavy metals in the environment and vended street foods has been established. The study therefore recommends as follows:

1. To enable official recognition and control of the Ready-to-eat street food industry as an integral part of the food supply chain, appropriate regulations should be prepared, and incorporated into existing food regulations in the country and Rivers State in particular.

2. Government to partner with private sector to carry out comprehensive outdoor air quality in Port Harcourt and Obio -Akpor Local Government area respectively to serve as a protection to public health and consumer interest.

\section{References}

[1] Otene, B. B. \& Alfred-Ockiya J. F. (2019). Human and Ecological Risk Assessment of Heavy Metals in Water and Sediment of Elechi Creek, Port Harcourt, Nigeria. IOSR Journal of Environmental Science, Toxicology and Food Technology (IOSR-JESTFT). Volume 13, PP 01-07.

[2] Hussain, R. T., Ebraheem, M. K. \& Moker, H. M. (2012). Assessment of Heavy Metals ( $\mathrm{Cd}, \mathrm{Pb}$ and $\mathrm{Zn}$ ) contents in Livers of Chicken available in the local markets of Basrah City, Iraq. Bas. J. Vet. Res. 11 (1): 43.

[3] Pan X. D., Tang J., Chen Q., Wu P. G. \& Han J. L. (2013). Evaluation of direct sampling method for trace elements analysis in Chinese rice wine by ICP-OES. European Food Research and Technology, 236: 531-535.

[4] EPA (1985). US Environmental Protection Agency. An exposure and risk assessment for benzo [a] pyrene and other polycyclic aromatic hydrocarbons. Vol IV. Washington, DC: US Environmental Protection Agency. EPA Report No. 4-85020-V4.

[5] [IARC] International Agency for Research on Cancer. 1973. Certain polycyclic aromatic hydrocarbons and heterocyclic compounds. Monograph on the evaluation of carcinogenic risks of the chemical to man. Vol. 3. Lyon, France: World Health Organization.

[6] Alloway, B. J, \& Steinnes, E. (1999). Cadmium in soils and plants. Kluwer Academic Publishers; Anthropogenic additions of cadmium to soils; pp. 97-123.

[7] Morrow H. Kirk-Othmer (2001). Encyclopedia of chemical technology. John Wiley \& Sons, Inc.; Cadmium and cadmium alloys. pp. 471-507.

[8] Ekpo, K. O., Asia, I. O., Amayo, K. O. \& Jegede, D. A. (2008). Determination of $\mathrm{Pb}, \mathrm{Cd}$ and $\mathrm{Hg}$ in Surrounding Water and Organs of some Species of Fish in Ikpoba River in Benin City, Nigeria. International Journal of Physical Science, 3 (11): 289-292.

[9] Mohammed, A. A, Iniaghe, P. O., Okoro, H. K., Saliu, O. D. \& Adeoti T. P. (2016). Assessment of Heavy Metal Contamination in Vended Road-Side Snacks using Ilorin as a Case Study. Al-Hikmah Journal of Pure \& Applied Sciences, 3: 51-56.

[10] Sobukola, O., Adeniran, O., Odedairo, A. \& Kajihausa, O. E. (2010). Heavy Metal Levels of Some Fruits and Leafy Vegetables from Selected Markets in Lagos Nigeria. African Journal of Food Science, 4 (2) 389-393.
[11] Forastieri, V. (1997). Chemical Exposures: Children at Work Health and Safety Risks; International Labour Organization. Geneva. Pp 114-115.

[12] Baruthio, F. (1992). Toxic effects of chromium and its compounds. Biological trace elements Research. 32 (1-3): 145-153.

[13] Environmental Health and Safety (EHS) (2009). The health effects of mercury. Oklahoma State University.www.ehs.okstate.edu/training/mercury.htm.

[14] WHO, (1988). International Operator's Handbook for the Measurement of Background Atmospheric Pollution No. 491E.

[15] APHA (American Public Health Association) (1998). Standard methods for the examination of water and wastewater 20th Edition, Washington D. C.

[16] FMEnv (1991). Federal Environmental Protection Agency 1991. National Interim Guidelines and Standards for Industrial Effluent, Gases emission and Hazard s waste management in Nigerian.

[17] Smirjakova S, Ondrassovicova O, Kaskova A, Lakticova K (2005). The Effect of Cadmium and Lead Pollution on Human and Animal Health. Fol. Veter. 49: 31-32.

[18] TCEQ: Texas Commission on Environmental Quality (2017). Emissions Inventory Guidelines Published and distributed by the Texas Commission on Environmental Quality P. O. Box 13087 Austin TX 78711-3087.

[19] Williams Tamuno Alexander (2019). Assessment of Socioeconomic and Human Health impact of Black Soot on Residents in Port Harcourt. An unpublished dissertation submitted to the Institute of Petroleum Studie University of Port Harcourt in partial fulfilment of the requirement for the award of the Master of Science degree in Occupational Health and Safety (M. Sc.).

[20] Ajayi, A., \& Kamson, O. E (1983). Determination of Lead in roadside dust in Lagos city by atomic absorption spectrophotometry. Environ Int. 9: 397 - 400.

[21] Ogunsola, O. J., Oluwole, A. F., Osubiojo, I. O., Durosinmi, M. A., Fatusi, A. O., \& Ruck, W. (1994). Environmental Impact of Vehicular traffic in Nigeria. Health Aspects. Sci Total Environ. 146 (147): 111-116.

[22] Onianwa, P. C, \& Egunyomi, A. (1983). A Trace metal levels in some Nigerian mosses as indicators of atmospheric.

[23] Audu Pius, Y. Mohammed \& A. O. Aliyu (2014). Evaluations of Some Carcinogenic Organic Compounds in industrial effluents. Lambert Academic Publishing, Omniscriptum GmBH \& Co KG. Germany.

[24] Ede, P. N \& Edokpa, D. O. (2017). Satellite Determination of Particulate Load over Port Harcourt during Black Soot Incidents. Journal of Atmospheric Pollution, 2017, 5 (2): 55-61.

[25] Rivers State Ministry of Environment (2017). Report on Particulate Matter (Soot) Analysis Study on some Parts of Port Harcourt. Government of Rivers State of Nigeria, 16pp.

[26] SPDC (2017). Soot Report: Ambient Air Characterization of Selected Areas in Port Harcourt. Port Harcourt: Shell Petroleum Development Company of Nigeria.

[27] Eke-Ejiofor J \& Maxwell, U.S. (2019). Safety and Quality assessment of street vended roasted plantain (bole) in Port Harcourt, Rivers State, Nigeria. International Journal of Biotechnology and Food Science 7 (1): 9-13. 
[28] Zeleznik J (1994). Occurrence of Heavy Metals in Smoked Meat Products (In Slovak). Attestation. Thesis, Institute for Education of Veterinary Surgeons Ko5ice. p. 46.

[29] Jarup, L. (2003). Hazards of heavy metals contamination. Br. Med. Bull. 68: 167-182.

[30] Oyelola, O. T, Afolabi, M. I, Ajiboshin, I. O \& Banjoko, I. O (2013). Heavy metal and microbial contents of roadside roasted corn and plantain in Alimosho Local Government Area of Lagos State, Nigeria. International Journal of Research In Medical and Health Sciences. 3 (1).

[31] Adekunle, I. M, \& Akinyemi, M. F (2004). Lead levels of certain consumer products in Nigeria: A case study of smoked fish foods from Abeokuta. Food Chem. Toxicol. 42 (9): $1463-1468$.

[32] Opeolu, B. O., Adebayo, K., Okuneye, P. A., \& Badru, F. A. (2010). Physicochemical and Microbial Assessment of Roadside Food and Water Samples in Lagos and Environs. $J$. Appl. Sci. Environ. Manage. 14 (1) 29-34.

[33] Poonkothia, M. S. \& Vijayavathi, B. (2012). Nickel as an Essential Element and a Toxicant. International Journal of Environmental Science, 1 (4) 285-288.

[34] WHO, (1996). Essential safety requirements for the street vended foods (revised edition) Geneva: World Health Organization, Food Safety Unit.

[35] FAO/WHO (2007). Essential Safety Requirement for Street-Vended Foods: Revised Edition. Food safety division of food and Nutrition pp 4-27.

[36] Ojo, O. I., Ogundiran, M. B. \& Adebayo, O. L. (2015). Toxic and Essential Metals in Staple Foods Commonly Consumed By Students in Ekiti State, South West, Nigeria. International Journal of Chemistry, 7 (1): 155-160.

[37] Salama, A. K. \& Radwan, M. A. (2005). Heavy Metals (Cd, Pb) and Trace elements $(\mathrm{Cu}, \mathrm{Zn})$ Contents in some Foodstuffs from the Egyptian Market. Emirate Journal of Agricultural Science, 17 (1) $34-42$.

[38] Tegegne, W. A. (2015). Assessment of Some Heavy Metals Concentration in Selected Cereals Collected from Local Markets of Ambo City, Ethiopia. Journal of Cereals and Oilseeds, 6, (2) 8-13.

[39] World Health Organization (2014). Guide on safe food for travellers.

Http//www.who.int/foodsafety/publications/consumer/travelle r/en/index.html.

[40] Nicolas, B., Ominite, D., Odukoya, O. O, \& Ajayi, S. O (2014). Trace heavy metals in Nigerian Fish: lead and cadmium. Nigerian Journal of Nutr. Sci. 8: 105-113.

[41] Tapos Kormoker, Ram Proshad, Md. Saiful Islam, Md. Shamsuzzoha, Ayesha Akter \& Tanmoy Roy Tusher (2020) Concentrations, source apportionment and potential health risk of toxic metals in foodstuffs of Bangladesh, Toxin Reviews, DOI: $10.1080 / 15569543.2020 .1731551$.

[42] Oyet Gogomary Israel, Achinewhu Simeon Chituru, Kiin-Kabari David Barine \& Akusu Monday Ohwesiri (2020). Effects of Seasonal Variations and location on Proximate Compositions of vended Street Food in parts of Port Harcourt, Rivers State. Word Journal of Food Science and Technology. Vol. 4, No. 2, 2020, pp. 53-61. 